\title{
10 Facilitating access to information: understanding the role of technology in copyright law
}

\section{Leanne Wiseman and Brad Sherman}

\section{Introduction}

Copyright law is, and has always been, a creature of technology. From the printing press, the telegraph and the camera, through to the phonogram, the photocopier, the tape recorder, the personal computer and the Internet, technological developments have always driven and shaped copyright law. As well as creating new types of potential subject-matter, technology is also deeply implicated in the definition of the subject-matter of copyright (a subject-matter that has constantly been renegotiated in response, in part, to technological change). Technology also provides new ways to reproduce, distribute and consume copyright works. Both hero and villain, creator of opportunities and problems, generator of solutions as well as the means to counteract or circumvent those solutions: the role of technology in copyright law is complex, changing and contradictory.

The aim of this chapter is to explore the role that technology plays in facilitating access to information and creative outputs. To do this we will focus on the 1956 British Copyright Act that was, in part, introduced in response to a variety of technological changes that had occurred since the 1911 Copyright Act was passed. More specifically we wish to look at the way that copyright law reacted and responded to two of these technologies: namely, television and photocopying.

As well as being important topics of study in their own right, these studies also offer insights into some of the problems and issues currently confronting copyright law and policy. In part, this is because we are still using many of the legal techniques that were developed or modified in response to those technologies. They are also important because they can help us to assess some of the historical claims that underpin contemporary arguments and debates. Historical arguments take many forms; one of the most common being the comparative claim about how different a particular new problem is from what has gone before. For example, many claims have been made about how fundamentally different the problems 
posed by digital technologies are from those problems that have arisen previously. The same is also true for many of the solutions that have been developed to deal with these challenges. One of the benefits of looking at the way that copyright law has responded to technological change is that it enables us to assess some of the claims made about how different things are today. It also better equips us to understand problems as they arise. This does not mean that the past holds all the answers nor, for example, that digital technologies have not created a range of novel and unique problems that require fresh solutions. Rather, it is to make the simple point that we can only determine how different the problems created by a new technology are if we understand what preceded them.

When thinking about the way that copyright law interacts with technological change, it is important to note that it is not the technology itself that is of interest, so much as the changes that the technologies instigated and the challenges and opportunities that this created. Thus, for example, with the phonogram, it was the ability for live performances to be recorded and then reproduced at another time and place that was at issue. Likewise with the tape recorder, it was the ability for people to record music at home that was the problem. With this caveat in mind, we now turn to look at the way that copyright interacted with television and photocopying.

\section{Television broadcasting}

When television broadcasting started in Britain in 1932, it was a Londonbased experiment with a very small footprint of around 20,000 viewers. It quickly expanded to become a national institution with over 4.5 million licensed television sets in use by 1955 . Until the establishment of the commercial and independently operated TV network run by the Independent Television Authority (ITA) in 1955, television broadcasting in the United Kingdom was the exclusive domain of the British Broadcasting Corporation (BBC). The BBC, a public institution formed by Royal Charter in 1927, was seen as a national service funded through revenue raised through television licences paid by viewers, rather than through commercial sponsorship, advertisements or government handouts. ${ }^{1}$

One of the notable features of television from the early 1930s through to the mid-1950s was the pivotal role played by sport. ${ }^{2}$ Sport was a part

${ }^{1}$ See generally B. Sherman, 'Public Ownership of Private Spectacles: Copyright and Television', in B. Sherman and L. Wiseman (eds.), Copyright and the Challenge of the New (Frederick, MD: Kluwer Law International, 2012), pp. 221-50.

2 R. Haynes, 'A Pageant of Sound and Vision: Football's Relationship with Television, 1936-60' (1998) 15 International Yournal of the History of Sport 211-26, 212. 
of television from the outset. Indeed, John Logie Baird's first public exhibition of the new technology was of the Epsom Derby. Over time, the amount of sport that was televised increased dramatically. For example, in 1937 the Wimbledon tennis tournament and the Home International between England and Scotland were televised to a London-based audience of 2,000. In 1938, the BBC broadcast a football game from Arsenal's home ground at Highbury Stadium, England's game against the 'rest of Europe', the Cambridge-Oxford Boat Race, the Epsom Derby and the cricket test match between Australia and England. 1939 saw live broadcasts extend to include boxing, swimming, motor racing, polo and rugby. It is important to note that until the mid-1950s, the sporting events shown on television were always live-to-air; there were no prerecordings of events (which had ramifications for the way that television was regulated).

There were a number of reasons why sport was seen as a pivotal part of the future of television. One key reason was the popularity of sport, which translated into a strong demand for sport on television. In 1950, for example, 1,750,000 people watched the FA Cup Final, 475,000 watched the test matches against the West Indies, while 1,405,000 people watched the Cambridge-Oxford Boat Race. ${ }^{3}$ Another reason why there was so much political support for more sport on television was that the broadcasting of sporting events was seen as a way of helping to rebuild and reunite the nation in the post-war period. Sport on television was also seen as a way of selling television sets and of generating money for broadcasters.

The growing popularity of sport on television can also be attributed to technological improvements in the quality of outdoor broadcasts that occurred as a result of technical developments such as directional microphones, new waterproof cameras, improved zoom lenses, lightweight battery-powered transmitters (which allowed the $\mathrm{BBC}$ to televise events such as golf tournaments), the increased use of floodlights, the ability to use a series of different cameras to broadcast a single event (twelve cameras were used at the 1949 Cambridge-Oxford Boat Race, which allowed the $\mathrm{BBC}$ to provide a continuous picture of the race) and improvements in the quality of television sets.

The upshot of these various factors was that in the pre- and post-war periods, there was a widespread and growing demand for more and more sport to be televised. As these sporting events were nearly always held on private land, this meant that the $\mathrm{BBC}$ needed to obtain the consent of the promoters before they could enter into the sporting venues to broadcast. The problem, however, was that while some sporting promoters were

${ }^{3}$ Ibid., 212-13. 
willing to allow sport to be televised (particularly in the pre-war period), overall, promoters were suspicious about television. There were a number of reasons for this. One explanation was that television was seen as a threat to the pre-existing arrangements that many promoters had with press photographers and newspapers. Sports promoters were also fearful of the long-term effects of television-on attendance at live events. While major events such as the FA Cup Final, the heavyrveight boxing championships and Wimbledon were secure, there was concern about the impact that the televising of popular events would have on attendance at other, less popular, sporting events. These fears were substantiated by the findings of the Sports Advisory Committee - which was formed by the Postmaster General to look at the impact of television on live attendance at sporting events following a noticeable drop in attendance at the $1950 \mathrm{FA}$ Cup Final between Arsenal and Liverpool ${ }^{4}$ - that the televising of certain major events, such as the FA Cup Final, was having a negative impact on attendance at other sporting events. ${ }^{5}$

Yet another reason why promoters were reluctant to allow the $\mathrm{BBC}$ to broadcast sporting events was because the $\mathrm{BBC}$ was neither willing nor able to pay for the right to televise. Nor was the $\mathrm{BBC}$ willing to compensate promoters for the losses that arose as a consequence of an event being televised. Instead, the BBC paid a 'facility fee' that compensated promoters for the number of seats taken by the cameras. While BBC revenues were growing, by 1950 the most promoters had been offered to allow an event to be broadcast in the United Kingdom was $£ 250$, with the normal figure rarely being over 25 guineas. ${ }^{6}$ These difficulties were reinforced by the fact that there was nothing that could be done to prevent cinemas from rediffusing sporting events once they had been televised. This meant the loss of a potential revenue stream that could have been used to supplement the amount paid to promoters.

In this situation, one of the few options available to promoters was for them to exercise their common law right to exclude television cameras from the premises where an event was being held. The problem here was

4 The sports associations agreed to show 100 events per annum. Sports Television Advisory Committee, First Report (1951), HO 256/720 C476447, National Archives, p. 1.

5 The Committee found that, when the FA Cup Final was televised in 1950, attendance at first-class matches dropped by 8 per cent in London and 5 per cent in Birmingham; while second-class matches fell 22 per cent in London and 19 per cent in Birmingham. Ibid.

${ }^{6}$ E. Yvamy, 'Copyright Law Revision' (1953) Current Legal Problems 196, 205. See generally Richard Haynes, 'A Pageant of Sound and Vision: Football's Relationship with Television, 1936-60' (1998) 15(1) International fournal of the History of Sport 211; Richard Haynes, 'The Early Courtship of 'Television and Sport: The Case of Cricket, 1938-58' (2009) 36(3) Journal of Sport History 401. 
that there was little that promoters could do to prevent third parties from filming their events from outside of their property: whether from scaffolds built near perimeter fences, from neighbouring buildings or from planes using long-range lenses. Faced with a growing threat of over-the-fence broadcasting, whether by the BBC, newsreel operators or cinema chains, and the apparent lack of a legal remedy, promoters tried a number of technological and biological measures to prevent over-the-fence broadcasting. These included the erection of balloon barriers around grounds, the shining of torches into the lenses of cameras, and plans to release pigeons at games to prevent sporting events from being broadcast from planes flying overhead. While these technological protection measures may have provided some temporary relief, overall they were ineffective.

While the demand for sporting events on television was growing, sporting promoters were unhappy with the fees that they were being paid to allow their events to be televised. After a number of years of negotiation with no improvement, sporting promoters decided that they were no longer willing to allow their events to be televised without adequate compensation. Given that the BBC was unable to pay to broadcast, negotiations between the $\mathrm{BBC}$ and the sporting broadcasters ground to a halt. The consequence of this deadlock was, in effect, a ban on the broadcasting of sporting events. While the ban was not complete, nonetheless it was effective. For example, while the FA Cup Final had been televised in toto in 1948, 1949 and 1950, only half the game was televised in 1951, and none of the game was televised in 1952. As the boycott spread to national events such as the Epsom Derby and the Grand National, as well as a string of other events, the impact of the ban became more profound.

As the gap between what the public wanted and what the $\mathrm{BBC}$ could deliver grew, so too did the complaints voiced in Parliament, in letters to the editor and in newspaper articles. The need to find a political solution was reinforced by the way events such as the Scottish and English FA Cup Finals, test matches, the Boat Race, the Grand National, the Epsom Derby, the Five Nations rugby union internationals, Wimbledon and the Open Golf Championship were viewed. Instead of being seen as forms of (commercial) entertainment, these sporting events - which were largely organised by private organisations and conducted on privately owned land - were treated as public events that were 'owned' by the nation.

Faced with growing calls for a solution to be found, a number of legal options were mooted. The idea that key sporting events were public property led many to argue that the 'BBC should, as a matter of right, be given compulsory power's to televise any event on financial terms to be 
agreed or, in the event of a failure to agree, to be settled by arbitration'. While these 'march-in rights', which were seen as a 'compulsion' that would have facilitated negotiation, would have provided a solution of sorts, they were rejected on the basis that they were 'not British'?

Another remedy suggested to break the deadlock that was preventing sporting events from being televised was that 'a copyright should be created in sporting spectacles'. Under this proposal, promoters of sporting events would have had 'a copyright in their events exactly analogous to that of a man who promotes a pageant. A man who promoted a pageant has a copyright in his pageant and if it is televised and cinemas rediffuse it or it is shown to any hotels... he has a right to demand a fee... or to stop it'. Ultimately, this was rejected because it would have created further problems. ${ }^{8}$

A third legal remedy that the $\mathrm{BBC}$ mooted - and ultimately adopted in the 1956 Copyright Act - was to introduce a copyright in the televised image. The Gregory Committee - which was established by the post-war Labour government in 1950 to consider whether copyright law needed to be changed to accommodate technical developments which had taken place since 1911, notably in relation to photocopying, recording and broadcasting - was supportive of the BBC's claim for a copyright in the televised image. In part, this was because the Gregory Committee accepted that the position of the BBC was not in principle any different from that of a gramophone company or a film company, who had already been granted their own form of copyright. ${ }^{9}$ While the government accepted the majority of the wide-ranging recommendations made by the Gregory Committee (including those in relation to television), there was insufficient legislative time to allow for the recodification of the law of copyright that this would have required. The government decided, however, that there was time for a short non-party Bill 'to deal with the more pressing aspects' of copyright. ${ }^{10}$ Along with changes needed to ensure that Britain complied with its international copyright obligations, it was also felt that 'it was essential that something should be done to overcome the deadlock in relation to televised sport'. ${ }^{11}$ To this end, the

7 Report of the Copyright Committee, 1951-52 (Cmd 8662, London: HMSO. 1952), p. 69.

8 Ibid. $\quad 9$ Ibid., 41 , para. 117.

10 The government said it was planning to introduce a more comprehensive copyright Bill in the future. See P. Thorneycroft, "Copyright Law (Amending Legislation)", House of Commons Debates, 16 February 1955, vol. 537, col. 66.

11 Postmaster General, 'Letter to Peter Thorneyctoft', March 1953, HO 256/591 C476447, National Archives; No Televising of Derby: Fee Far from True Value', The Times, 19 March 1955, 4 ("without the Bill, the televising of the Derby will not be possibles). 
Copyright and Television Exhibiting Right Bill was muruuuceu liament in March 1955. ${ }^{12}$ After being postponed on 19 April 1955 due to lack of time, ${ }^{13}$ the Copyright and Television Exhibiting Bill became a legislative victim of the dissolution of Parliament that occurred in May $1955 .{ }^{14}$ Following the appointment of a new government, a new more comprehensive copyright Bill was introduced into the House of Lords on 26 October $1955 . .^{15}$ As part of the sweeping reform of copyright, the Copyright Bill proposed to deal with the 'television problem'. To this end, clause 14(4) of the Bill proposed to give broadcasters (the BBC and the recently formed Independent Television Authority) a right to prevent: (a) filming the broadcast; (b) recording the sound content of the broadcast (otherwise than for private purposes); (c) showing the broadcast to the public; and (d) rebroadcasting. The duration of the right was changed from twenty-five years to fifty years as a result of an opposition amendment. ${ }^{16}$

After further fine-tuning, broadcast copyright was introduced into British law when the 1956 Copyright Act received royal assent on 5 November 1956. By the time the 1956 Act was passed, broadcast copyright (or at least the prospect thereof) had already done its job: it had resolved the deadlock between sporting promoters and broadcasters that had restricted sport on television.

\section{The photocopier}

The second technology that the 1956 Copyright Act responded to was the photocopier. ${ }^{17}$ The photocopier was invented in 1942 by the New York-based patent attorney, Chester Carlson. Carlson's motivation to begin the work that would ultimately lead to the development of the photocopier was his frustration with the fact that there was no quick and practical way of making the copies he needed for his work.

12. Lord Mancroft, 'Copyright and Television Exhibiting Right Bill (HL)', House of Lords Debates, 15 February 1955, vol. 191, col. 8 (1st reading); House of Lords Debates, 22 March 1955, vol. 192, cols. 29-62 (2nd reading).

13 V. Wolton (Chancellor), 'Business of the House', House of Lords Debates, 19 April 1955, vol. 192 , col. 402 .

14 Prime Minister Churchill resigned in April 1955 due to ill health. Following Sir Anthony Eden's appointment as leader of the Conservative Party on 21 April 1955, Parliament was dissolved on 6 May. A general election was held on 27 May 1955 (which returned another Conservative government).

15 Announced in the Queen's Speech on 9 June 1955.

16 See 'Copyright in Broadcasts: Period Extended to 50 years', The Times, 13 July 1956, 7.

17 See generally L. Wiseman, 'Making Copies: Photocopying and Copyright', in B. Sherman and L. Wiseman (eds.), Copyright and the Challenge of the New (Frederick, MD: Kluwer Law International, 2012), pp. 197-220. 
The development of copying machines that were quick, simple and (relatively) easy to use, combined with a decision to rent rather than sell copiers, ensured their widespread uptake and use. The popularity of photocopying was further enhanced by the introduction of coinoperated photocopiers, which were designed to be 'a vending machine, like coffee machines, cigarette machines or candy machines'. Within a very short period of time, photocopiers became a stable fixture in businesses, libraries, schools, universities and government agencies in most developed countries. Specialist 'copying emporiums' also began to spring up 'behind newsstands, above markets, in bare walled buildings, wherever the rent [was] reasonable enough to insure a profit from the traffic in theses, invoices, notes, resumes, and other printed material'. ${ }^{18}$

Along with the tape recorder; the modern photocopier changed the nature of copying. As one commentator noted at the time, photocopying changed 'copying into a completely different animal. Proof of this can be found in one simple fact: no one in the twentieth century has made a living by selling pen and pencil copies of articles. ${ }^{19}$ The photocopier brought about three important changes in copying practices that are relevant here. The first was in terms of the place where the copying occurred. Prior to the development of electrophotography only very large organisations, such as the US Library of Congress and the British Library, could afford copying equipment. One of the consequences of the introduction of affordable and usable photocopy machines was that the sites where copying occurred changed. Rather than being limited to a small number of large organisations, copying now occurred in a range of locations including libraries, small businesses, offices, universities and schools. Document copying had, in effect, been decentralised.

The photocopier also changed the people who did the copying. The fact that copying technologies such as the photostat camera and microfilm were difficult to operate meant that prior to the introduction of the modern photocopier, copying was normally done by specialists with the requisite expertise. One of the advantages of the new photocopiers was that they could be operated by virtually anyone. The fact that the new easy-to-operate machines were available in a range of accessible venues meant that a greater number of people were able to access and use the copying technologies. The introduction of coin-operated machines also meant that the new machines did not have to be supervised; they could be

18 W. R. Hawken, Photocopying from Bound Volumes: A Study of Machines, Methods, and Materials (Chicago: American Library, 1962), pp. 53-4.

19 G. A. Gipe, Nearer to the Dust: Copyright and the Machine (Baltimore, MD: Williams \& Wilkins, 1967), p. 245. 
used by members of the public in the library (or newsagent, restaurant or menswear shop) without the assistance of a member of staff. For the first time, the introduction of easy-to-use coin-operated photocopiers allowed office workers, library staff, government employees and students to make cheap and quick copies themselves. ${ }^{20}$ As a result, copying practices, and eventually copyright law, would never be the same again.

Photocopying also increased the amount that was copied. For example, it was estimated that around 3.6 billion photocopies were made in 1962 in the United States alone. ${ }^{21}$ While we should be sceptical about these figures (not least because they were produced by organisations with a vested interest in exaggerating the scale of the photocopying problem), it is clear that photocopying did lead to an exponential increase in the amount of copying that was taking place. ${ }^{22}$

In the United Kingdom, copyright law's interaction with the photocopier occurred in two stages. Initial responses to the photocopier were positive: particularly in relation to the role that the new copying technologies were able to play in improving access to scientific and technical information. As the rapid increase in the amount of copying facilitated by photocopying, particularly of books and journal articles, began to threaten the economic interests of copyright owners, the focus of attention shifted from access issues towards the question of how owners should be compensated for the increased copying. While the way that copyright owners were compensated for the increase in copying brought about by photocopying is important, we will limit ourselves here to the role that the new technology played in improving access to information.

\section{Photocopying as a means to improve access to information}

One of the issues that the Gregory Committee considered was whether or not and if so how copyright law could be modified to ensure that the potential offered by the photocopier could be actualised. One suggestion made by the Committee was that provisions designed to facilitate copying in libraries should be introduced. In designing a statutory mechanism that

D. Owen, Copies in Seconds: How a Lone Inventor and an Unknown Company Created the Biggest Commtnication Breakthrough Since Gutenberg - Chester Carlson and the Birth of the Xerox Machine (New York: Simon \& Schuster Paperbacks, 2004), p. 236.

21 N. Henry, 'Copyright, Public Policy and Information Technology' (1974) 183 Science $384-91,387$.

22 The disease quickly spread from the United States to other countries. For example, in 1973 over 1,750,000 copies were made in the University of New South Wales library. Of these, 1,180,000 were made on self-service machines. P. Banki, 'Submission to the Copyright Law Committee on Reprographic Reproduction' (Australian Council for the Arts, 29 October 1974), Annexure A, 3. It led to the classroom guidelines. 
wvun uo uns, me Gregory Committee based its proposed new scheme on the Royal Society's Fair Copying Declaration, which was issued in June $1950 . .^{23}$ As the Committee said, 'we have noted with interest the arrangements which have been concluded between the Royal Society, individual Scientific Societies, and many of the publishers of scientific periodicals'. ${ }^{24}$

The Fair Copying Declaration was a product of the Royal Society Information Conference, which ran for ten days in 1948. One of the issues discussed at the conference was what was to be done to improve access to scientific literature. In part, access to information had become a problem because of the dramatic increase in the number of scientific publications that had been 'stimulated by the needs of wartime and then by liberation of peace'. ${ }^{25}$ The rapid increase in scientific literature, which was estimated in 1948 to 'total anything up to a million published items a year', created a situation where it was impossible for an individual to 'scan more than an infinitesimal fraction' of a field. ${ }^{26}$ 'The proliferation in the amount of information being published placed enormous pressure on the already struggling sciences. ${ }^{27}$ It also led to the fear that scientists would not be able to control the vast amounts of 'potentially relevant material that were pouring forth from the world's presses', ${ }^{28}$

The problems created by the rapid increase in the amount of science that was being published were compounded by the fact that a growing number of scientists were working in remote and isolated locations around the world. The problem with the decentralisation of science was that there was no guarantee that scientists would be able to access the information that was stored in the research and university libraries that tended to be based in large metropolitan cities. ${ }^{29}$ As it was not feasible to establish research libraries in all of the locations where research was (now) carried out, it was felt that new mechanisms were needed to ensure that every scientist 'no matter where he may be, has access to the

23 'Microfilm and Copyright', Paper No. 40 prepared by Bristow's, Cooke and Carpmael in the Royal Society Scientific Information Conference, 21 June-2 July 1948: Report and Papers Submitted (London and Aylesbury: Hazell, Watson \& Viney, 1948), pp. 540-3.

24 Ibid, para. 45.

25 M. Line, 'An Information World Apart: The Royal Society Scientific Information Conferences of 1948 in the Light of 1998' (1998) 554 fournal of Documentation 284-92, 285.

${ }^{26}$ H. Fox, "The Royal Society Scientific Information Conference', Nature, vol. 162, No. 4112, 21 August 1948, 279.

27 The Royal Society Scientific Information Conference, 21 June-2 July 1948: Report and Papers Submitted (London and Aylesbury: Hazell, Watson \& Viney, 1948), p. 20.

28 Ibid. ${ }^{29}$ Ibid. 
recorded record of science to the full extent to which it can contribute to his investigations', 30

In thinking about how access to information might be improved, attendees at the Royal Society Information Conference highlighted the important role that new reproductive technologies, notably microfilm and the photocopier, were able to play in disseminating scientific information. More specifically, it was suggested that one way in which the access problems confronting post-war science might be resolved was for libraries to reproduce and disseminate material for scientists. Lord Chorley captured the prevailing view about the important role that photocopiers potentially played in facilitating access to information when he said:

[T] he library is perhaps the most vital tool of modern scholarship, and the facilities provided by present-day libraries are really quite remarkable. They enable the scholar, sitting in his study, to draw upon archives from all over the world by means of modern photographic processes and particularly by means of the remarkable process of photostatic reproductions of all kinds of things, including texts from ancient scripts, passages from modern works and the photographs of pictures in all the galleries of the world. ${ }^{31}$

Whatever merit there might have been in the suggestion that the new copying technologies offered a solution to the access problems that had arisen in the post-war period, it quickly became clear that for this potential to be fulfilled it was first necessary to deal with another problem, namely, the fear that copyright might inhibit the potential of the new technologies to enhance the dissemination of information. ${ }^{32} \mathrm{Here}$, the primary question was what could be done to ensure that copyright law did not hinder or limit this new-found potential.

Copyright imposed a number of barriers that limited the photocopier from being used to its full potential to improve access to information. One such problem was the time and expense involved in obtaining the permission needed to copy. Given that libraries and information services were often unable or unwilling to obtain the requisite permissions, this meant that the obligation to obtain the necessary consent fell upon the person who was asking for a document to be copied. This led to 'much tedious correspondence and considerable delay. And because such restrictions exist many libraries are unwilling to install copying facilities. ${ }^{33}$

31 Lord Chorley, 'Copyright Bill', House of Lords Debates, 29 November 1955, vol. 194, col. 904.

32 The Royal Society Scientific Information Conference, 197, recommendation 3.2 .

33 The Royal Society Information Services Committee, Fair Copying Declaration and List of Publishing Organisations Subscribing to It (London: Royal Society, 1950), p. 3. 
Another factor that hindered photocopying was the fact that in the post-war period librarians, scientists, researchers and their legal advisors believed that the law did not provide them with a defence that enabled them to take advantage of the new copying technologies. One reason for this was the uncertainty that existed about the scope and nature of the fair-dealing defence: which was the only real defence available to users at the time. One source of confusion was the fact that it was unclear how much could be copied under the Act. As one commentator complained, the British Copyright Act of 1911 was 'guilty of causing (or more accurately of perpetuating) uncertainty among the general public as to the extent to which published works might be reproduced'. ${ }^{34}$

The uncertainty about the amount that could be copied under the fair-dealing defence was compounded by the fact that in the post-war years 'research' or 'study' were not defined by the relevant legislation; nor was there any relevant case law. As the Lord Chancellor said, 'there are some difficulties with regard to fair dealing. So far as I know, the term has never been defined in the courts. Obviously, it is difficult to define. ${ }^{.35}$ Another factor that limited the usefulness of the fair-dealing defence was the belief that it did not provide protection for a person (such as a librarian) who copied on behalf of other scholars. While there was no case law on point, Copinger and Skone James argued that private study only covered 'the case of a student copying out a book for his own use, but not the circulation among other students'. ${ }^{36}$ This was taken to mean that, for fair dealing to qualify as 'research', it must 'be done for oneself (or one's employers), and not produced wholesale for others'. ${ }^{37}$ While allowing a third party to copy on behalf of a legitimate user may have appeared 'simply to be an economical conservation of resources', nonetheless it was thought that fair dealing 'would not apply, leaving the copier open to a charge of infringement'. ${ }^{38}$ The concerns about the uncertain nature of the fair-dealing defence were compounded by the

${ }^{34}$ L. Wilson, 'Copyright and the Scientist', Nature, vol. 170, No. 4339, 27 December 1952, 1108; R. Shaw, 'Royal Society Information Conference', Science, New Series vol. 108, No. 2798, 13 August 1948, 148-51, 150; F. E. Skone James and E. P. Skone James (eds.), Copinger and Skone James on the Law of Copyright (9th edn, London: Sweet \& Maxwell, 1958), p. 230.

35 The Lord Chancellor, 'Copyright Bill', House of Lords Debates, 29 November 1955, vol. 194, col. 910 .

36 F. E. Skone James and E. P. Skone James (eds.), Copinger and Skone fames on the Laxy of Copyright (10th edn, London: Sweet \& Maxwell, 1965), p. 177.

37 Ronald Barker, Photocopying Practices in the UK (London; Faber \& Faber, 1970), p. 20.

38 E. P. Skone James (ed.), Copinger and Skone fames on Copyright (11th edn, London: Sweet \& Maxwell, 1971), para. 462. See also W. R. Cornish, 'Photocopying, Libraries and the Copyright Law of the United Kingdom' (1976) 4 International fournal of Law Libraries 26-31, 27. 
fact that there were doubts about whether the defence applied at all to machine-based copying. Underpinning these concerns was the question of whether the fair-dealing provisions were technologically specific and limited to hand copying, or whether they could be extended to mechanical copying. ${ }^{39}$ These various factors combined to create a situation where copyright was seen to inhibit the uptake and adoption of the photocopier. As a result, copyright law came to be seen as a major stumbling block to the plan to use the new reproductive technologies to improve access to scientific information. ${ }^{40}$

In responding to the problems created by copyright, the Royal Society canvassed a number of possible solutions. One option explored by the Royal Society was the possibility of adopting a private agreement between publishers, authors and users along the lines of the 1935 Gentlemen's Agreement, ${ }^{41}$ which set out the amount of copyright material which libraries in the United States were able to copy on behalf of researchers. After some discussion and further work, in 1950 the Information Services Committee of the Royal Society issued the Fair Copying Declaration. This Declaration, which was seen as a practical means of solving a problem, rather than a legal formula, was designed to ensure that 'scientists have no undue difficulties in obtaining copies from libraries and other organisations supplying information'. The Fair Copying Declaration provided that signatories to the Declaration 'will regard it as fair dealing for the purpose of private study or research when a non-profit making organisation, such as a library, archives office, museum or information service, owning or handling scientific or technical periodicals published by us makes and delivers a single reproduction of a part of an issue thereof'. 'The scheme proved to be very popular. This was reflected in the fact that by 1 May 1950 there were 118 subscribers to the Declaration. These consisted of 100 learned scientific bodies including the

${ }^{39} \mathrm{~S}$. Allan et al., "New Technology and the Law of Copyright: Reprography and Computers' (1968) 15 UCLA Law Review 939-1030, 951.

40 These problems were exacerbated by the fact that there was some uncertainty about the validity of the fair-dealing defence. As the Lord Chancellor said: ' $[A]$ s I indicated earlier on, it finds no place in either two of the Conventions. Its insertion in our law has probably been allowed to pass because up to now it has been used only de minimis. We must face the point. We are all being responsible in this matter; we are all anxious that we should be within the Convention. We must face the point that any considerable widening of its scope is most likely to attract attention, and therefore the question must be approached with care, because basic copyrights are involved.' The Lord Chancellor, 'Copyright Bill', col. 910.

41 The Gentlemen's Agreement is available at (1939) 2 Documentary Reproduction 29, 31-32. For a general discussion, see Peter Hirtle, 'Research, Libraries, and Fair Use: The Gentlemen's Agreement of 1935' (2006) 53(3-4) fournal of the Copyright Society of the USA 545. 
British Association for the Advancement of Science, the Institution of Mechanical Engineers, the Society for Applied Bacteriology, the Royal Society, and the Zoological Society of London. Eight publishers also subscribed to the Declaration including Butterworths, Cambridge University Press, Clarendon Press, Heffer \& Sons, His Majesty's Stationery Office, and Macmillan \& Co. ${ }^{42}$ Combined together, the learned societies and publishers represented over 170 journals of 'great scientific interest'. ${ }^{43}$ Users of journals covered by the Declaration were notified of the fact that the journal in question was subject to the Fair Copying Declaration. For example, the notice to contributors section of the Quarterly fournal of Medicine, which was published by Oxford University Press, included the statement that the 'publishers are signatories to the Fair Copying Declaration in respect of this journal'. While the inclusion of the leading publishing companies was important in the operation of the Declaration, the Fair Copying Declaration was underpinned by the fact that many of the leading scientific journals were published by learned scientific societies. For example, the Institute of Physics and the Physical Sciences published the British fournal of Applied Physics, the Mineralogical Society published the Mineralogical Magazine, and the Mathematical Institute published the Quarterly fournal of Mathematics. When the Fair Copying Declaration was first issued in 1950, organisations were invited to subscribe for a two-year period. ${ }^{44}$ The fact that the Declaration was reissued in $1952^{45}$ and $1957^{46}$ suggests that it was, at least in the eyes of the Royal Society, a success. The widespread membership of the scientific and learned societies and the fact that their publications were widely distributed meant that the Fair Copying Declaration operated in many different countries. ${ }^{47}$

Given the success of the Fair Copying Declaration, it was not surprising that the Gregory Committee used it as the foundation for the proposed library copying provisions. As the Committee said, 'with little

42 Many of the publishing companies only subscribed in relation to certain publications.

43 The Royal Society of London Information Services Committee, Fair Copying Declaration and List of Publishing Organisations Subscribing to It (London: Royal Society, 1950), pp. 9-11.

44 Ibid., 3.

45 Royal Society of London Information Services Committee, Fair Copying Declaration and List of Publishing Organisations Subscribing to It (2nd edn, London: Royal Society, 1952).

${ }^{46}$ Royal Society of London Information Services Committee, Fair Copying Declaration and List of Publishing Organisations Subscribing to It (3rd edn, London: Royal Society, 1957).

47 The Declaration was adopted by learned bodies based in Commonwealth countries such as the New Zealand Crown Research Institute in relation to the fournal of Forestry Science. 
modification the arrangements negotiated by the Royal Society are susceptible of general application without prejudicing the income which either publisher or author derives from periodical publications'. ${ }^{48}$ The proposals made by the Gregory Committee were accepted by the British government and implemented in section 7 of the Copyright Act 1956 and the Copyright (Libraries) Regulations $1957^{49}$ (which were issued by the 'Board of Trade in consultation with the Royal Society and the Libraries Association). In essence, these provisions allowed libraries, in certain circumstances, to copy articles from periodicals, parts of published works, and the complete works for use by other libraries. While other issues, notably the status of fair dealing in relation to machine-based copying remained unclear, nonetheless in so far as the library copying schemes provided libraries with the confidence to photocopy, they helped to overcome one of the obstacles that stood in the way of the photocopier being used to improve access to information.

\section{Conclusion}

The 1956 Copyright Act marked an important development in twentiethcentury copyright law in the United Kingdom (and in the many countries that based their laws on the British legislation). There are two notable features of the way that British copyright law interacted with these new technologies.

The first notable feature of the way copyright law responded to these new technologies relates to the form that these legal responses took. When broadcast copyright was being developed, it was seen as a way of resolving the deadlock that had prevented sport from being televised. By the time a legislative solution had been found, however, sport - along with content more generally - had disappeared from the picture. While the proposed new rights had been designed to deal with the problem of sport on television, they were not limited to sporting broadcasts but applied, instead, to all broadcasts. We get a sense of the reason for this from the notes drafted by the Post Office to assist Lord Mancroft in preparing for his second reading speech on the 1955 Copyright Bill which suggested that he might want to address the question: '[W] hy not confine the performing right in television to sporting events, since these are the main reason for its creation?' The answer suggested by the Post Office was that '(a) [t]he difficulty of defining what events should give rise to a performing

48 Report of the Copyright Committee, 1951-52 (Cmd 8662, London: HMSO, 1952), para. 46.

49 Copyright (Libraries) Regulations 1957, SI 1957 No. 868. 
theatrical producer should be given the same opportunity to have extra remuneration from the public showing of his production and the same opportunity to ask for its public showing to be controlled as the sports promoter ${ }^{50}{ }^{50}$ Instead of only granting rights to sporting promoters, the legal rights that were designed to allow more sport to be televised were recast in a non-discriminatory way so that they applied to all broadcasts. In so doing, the focus of attention shifted from the content of what was communicated to the mechanism that allowed content, any content, to be communicated to the public.

A similar pattern also occurred in relation to the library copying provisions. While the Fair Copying Declaration was based upon the idea that the making of single copies of extracts from scientific books and periodicals was essential to researchers, nonetheless the Gregory Committee and in turn the British government believed that it ought to be extended to all forms of study. As with television copyright, the library copying provisions were recast in an abstract non-discriminatory form.

There are a number of consequences of this change in form. One of these is that it should force us to rethink how we look at the history of copyright (or at least aspects thereof). For example, most accounts of broadcast copyright start with the provisions in the 1956 Copyright Act, which are used as a reference point when going forwards and backwards. One of the problems with this in the case of television is that it leads us to focus on the mode of communication (the broadcast), rather than on what was to be communicated (sport). It also leads us to look for certain types of justifications or explanations for broadcast copyright (as a way of encouraging investment), rather than regarding it as a means of resolving a specific problem (how to get more sport on television). One of the most important consequences of this history is that we need to be careful about the lessons we take from the past. The disjuncture between the problems that led to the establishment of broadcast copyright and the library copying defences and the form that the legal solutions ultimately took means that we need to question the role that a history of the emergence of the legislative provisions is able to play in explaining copyright law following the passage of the 1956 Act.

Another reason why it is important that we pay attention to the form that a particular law takes is that the process of abstraction may hide subtle but important changes. For example, at the time the library copying provisions were enacted they were presented as if they were nothing 
more than an expanded version of the Fair Copying Declaration recast in a statutory format. While there is no doubt that the Declaration acted as the foundation for the library exceptions, the suggestion that the new provisions merely extended and gave force of law to a pre-existing private agreement masks the subtle but important changes that occurred at the time. In particular, it hides the fact that the model of creation, circulation and consumption underpinning the library copying provisions was fundamentally different to the model employed under the Declaration. In particular, while the Fair Copying Declaration was based on a consensual model that saw authors, publishers and users working together towards a common goal, the library provisions were based on an oppositional model that presumed that the interests of authors and publishers were fundamentally opposed to the interests of users. It was also a legal model: that is, one that ensured that authors and publishers were linked by law, rather than agreement.

The change from a shared to an oppositional legal model that occurred with the library copying provisions was neither inevitable nor necessary. Rather, it was a consequence of the particular way that publishers and authors were portrayed. In part, the reason for this change can be traced to the fact that the library copying provisions not only extended the remit of the type of person who was able to benefit from the defence, they also expanded the types of journals and, more importantly, the types of publishers who were affected by the copying. While there was an opportunity in the library provisions to recognise that publishers and authors were motivated by both commercial and non-commercial ends, this did not occur. Instead, most of the discussions, along with the resulting rules and procedures, were based upon the assumption that publishers and authors were driven by commercial motives. While commercial considerations were taken into account when the Fair Copying Declaration was formulated, they were subservient to the overarching goal of ensuring access to information.

A second lesson that we can draw from a better understanding of the way that British law interacted with television and with photocopying is that there is nothing inevitable about the way that the copyright law responds to and deals with technological change. With television, for example, copyright was seen as a solution, as a way of breaking a deadlock that prevented sport from being televised. With the photocopier, however, technology was initially seen as a means to facilitate access to information. Here, copyright was seen as something that hindered the use of that technology, and thus something that undermined access to information. Over time, copyright also came to be seen as a mechanism 
that could be used to protect copyright owners from the radical changes in copying practices that had been facilitated by the photocopier. The upshot of this is that, while it seems that technology will continue to shape the future of copyright, there is nothing certain about what that future will look like. 